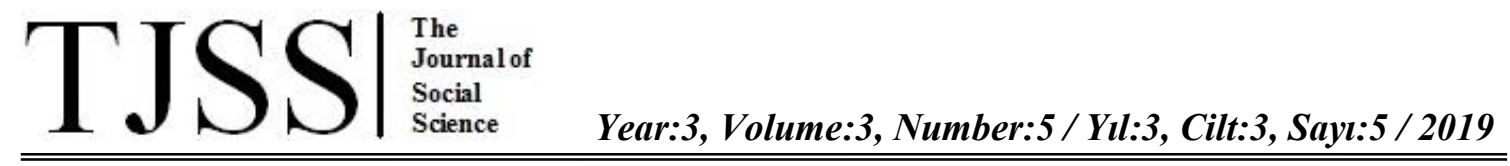

DOI Number: 10.30520/tjsosci.518584

\title{
YEREL YÖNETIMLERDE AFET ZARARLARININ AZALTILMASI ÇALIŞMALARINA GENEL BİR BAKIŞ
}

\author{
AN OVERVIEW OF APPLICATIONS OF DISASTER MITIGATION IN LOCAL \\ GOVERNMENTS
}

Serpil GERDAN ${ }^{1}$

\begin{abstract}
ÖZET
Afetler insan toplulukları ve yerleşim alanları üzerinde çok yönlü kayıplar meydana getiren, normal yaşamı ve insan faaliyetlerini bozarak veya kesintiye uğratarak toplulukları etkileyen, doğal, teknolojik veya insan kökenli olayların sonuçları olarak tanımlanmaktadır. Afet risklerinin yönetimi için gerekli risk ve zarar azaltma çalışmaları ülkemizin de içinde bulunduğu Sendai Çerçevesi (2015-2030) Eylem Planı doğrultusunda şekillenmekte ve çok disiplinli bir işbirliği gerektirmektedir. Bu çalışmada, kentleşmeyle birlikte topluluklar üzerinden büyük yıkımlara neden olan afetlerin olumsuz sonuçlarının azaltılmasına yönelik yürütülen zarar azaltma çalışmaları yerel yönetimler ölçeğinde değerlendirilmiştir. Yerel yönetimler hem kentsel altyapı ve kentsel dönüşüm çalışmaları ile afet zararlarının azaltılması açısından risk yönetimine hem de sosyal sorumluluk hizmetleri ile afet öncesi, sırası ve sonrası zarar azaltma faaliyetleri ile afet yönetimine katkı sağlamaktadır. Yeni düzenlemelerle büyükşehir, il ve ilçe belediyeleri ülkemizde afetlerden sorumlu kurum olan Afet ve Acil Durum Yönetim Başkanlığının (AFAD) il müdürlükleri ile işbirliği içerisinde zarar azaltmaya yönelik birçok proje üretmektedir. $\mathrm{Bu}$ düzenlemelerle yerel yönetimlerin ülkemizdeki zarar azaltma etkinliğinin artırılması amaçlanmakla birlikte henüz uygulama açısında gelinen durum istenilen seviyeye maalesef ulaşamamıştır.
\end{abstract}

Anahtar Kelimeler: Zarar azaltma, yerel yönetim, kentsel planlama

\footnotetext{
${ }^{1}$ Dr. Öğretim Üyesi, Kocaeli Üniversitesi, İzmit Meslek Yüksekokulu, Türkiye, sgerdan@kocaeli.edu.tr
} 


\begin{abstract}
Disaster is defined as the result of, caused by nature or human origins, a sudden, calamitous event that seriously disrupts the functioning of a community or society and causes human, material, and economic or environmental losses that exceed the community's or society's ability to cope using its own resources. Risk and mitigation applications for management of disaster risks are shaped according to Sendai Framework (2015-2030), which includes our country and requires multidisciplinary cooperation. In this study, the disaster mitigation efforts carried out to reduce the damages of the disasters that caused great destruction with the urbanization were evaluated for the local governments. Local governments contribute to disaster management with urban infrastructure and urban transformation studies, risk management of disaster mitigation, and social responsibility services as well as disaster mitigation before, during and after the disaster. With the new regulations, metropolitan, provincial and district municipalities produce many projects to reduce disaster damages in cooperation with the provincial directorates of the Disaster and Emergency Management Presidency (AFAD) in Turkey. Although these regulations aim to increase the efficiency of local governments in disaster mitigation in our country, the situation in terms of implementation has not reached the desired level.
\end{abstract}

Keywords: Mitigation, local government, urban planning

\title{
GíRiş
}

Afetler, Ergünay, (2002) tarafından insanlar için fiziksel, ekonomik ve sosyal kayıplar doğuran, normal yaşamı ve insan faaliyetlerini durdurarak veya kesintiye uğratarak toplulukları etkileyen ve etkilenen topluluğun kendi imkan ve kaynaklarını kullanarak üstesinden gelemeyeceği, doğal, teknolojik veya insan kaynaklı olaylar olarak tanımlamaktadır. Bir başka ifade ile tehlikelerin hazırlıksız toplumlar üzerindeki olumsuz sonuçları afet olarak tanımlanmaktadır. Can ve mal kayıpları, yaralanmalar, yapısal ya da yapısal olmayan hasarlar, ekonomik, psikolojik sorunlar ve sosyal hayatı ilgilendiren bütün kayıplar bu sonuçlar içerisinde değerlendirilebilir. Bu kayıpların büyüklügü aynı zamanda afetin büyüklügünü belirleyen bir unsurdur. Diğer taraftan insan hayatının önemi nedeniyle can kayıplarının miktarı yani ölüm oranı afetin büyüklügü ile özdeşleştirilmektedir. Afetin büyüklügünü etkileyen faktörler ile afetlerden kaynaklanan kayıpların düzeyi toplumun hazırlık düzeyi ile doğru orantılı olarak artmakta veya azalmaktadır (Ergünay, 2002; Ergünay, 2006).

Literatürde afetlerin etkileri direk etkiler ve dolayı etkiler olarak iki ana başlıkta ifade edilmektedir. Direk etkiler tehlikenin hemen ardından ortaya çıkan ve aslında o tehlikeyi afet olarak niteleyen ölüm, yaralanma, yıkım, çevrenin tahribi, iletişim, ulaşım altyapısında meydana gelen hasarlar ve diğer tüm olumsuzluklar olarak açıklanabilir. Dolaylı etkiler ise orta ve uzun vadede doğrudan etkiler sonucu ortaya çıkan aksaklıkları ifade eder (Yavaş, 2005). Değişen ve gelişen dünyaya paralel olarak yönetim stratejilerindeki değişimler toplum merkezli, çok aktörlü ve çok katılımlı olma, çözümlerde ortaklık ve yönetişim gibi yeni yönetim anlayışlarını da beraberinde getirmektedir (Toprak Karaman, 2000; Yavaş, 2005). Birleşmiş Milletler, 1990-1999 yılları arasını "Uluslararası Afet Zararlarının Azaltılması On Y1lı (IDNDR)" olarak ilan etmiştir. Bu sürecin amacı, uluslararası toplumun doğal afetlerin en aza indirgenmesinde uluslararası işbirliğini teşvik etmektir. $\mathrm{Bu}$ işbirliği ve dayanışma ile özellikle kalkınmakta olan ülkelerin doğal afetlerden etkilenme oranının can kaybı, mal kaybı ile ekonomik ve sosyal kayıpları açısından en az miktara indirgenmesi hedeflenmiştir. Bu on yıl sürecinde ülke ölçeğinde yapılacaklar arasında "Yerel yönetimlerin ve özel 
sektörün devreye sokulması ve bunların 10 yıl hedefine uygun çalışmalarının teşvik edilmesi" yer almaktadır. 2005-2015 yılları arasında afet zararlarının azaltılmasında Birleşmiş Milletler kaynaklı bir yol haritası olarak Hyogo Çerçeve Eylem Planı (HFA) hayata geçirilmiştir. Planın birinci ve en önemli maddesi; risk azaltmanın öncelikli plan olarak kabul edilmesidir ve yasal çerçevelerinden birini afet risklerinin azaltılmasında yerel kaynakların güçlendirilmesi oluşturmaktadır. HFA aynı zamanda sorumlulukların ve kaynakların merkezileşmeden yerelleşmeye doğru yönlendirilmesi konusuna öncelik vermektedir (Kuterdem ve diğ., 2009). HFA'nın, afet zararlarının azaltılmasına yönelik öncelikli olarak sunduğu 5 önemli eylem arasında "Mümkün olan her türlü bilgiyi kullanarak direnç kültü̈rünün oluşturulması ve farkındalığın artırılması" yer almaktadır. Hyogo Eylem Planının devamı niteliğinde olan Sendai Eylem Planı (20152030); 2020 yılına kadar ulusal ve yerel afet riskini azaltma stratejileri uygulanan ülke sayısını önemli ölçüde artırılmasını hedeflemektedir (Kırıkkaya ve Varol, 2017; Macit, 2019; URL-1). Ayrıca Birleşmiş Milletler Afet Zararlarını Azaltma Ofisi-UNISRD (The United Nations Office for Disaster Reduction) yerel yönetimlerin afet riskini azaltmak ve afete dirençli toplum oluşturma konularına dikkat çekmek amacıyla 2010 yılında "Dirençli Kentler Kampanyası" başlatmıştır. 2015 yılına kadar süren bu kampanya da risk azaltma çalışmalarında başarılı olan kentler ödüllendirilmiştir. Col (2007) bir çalışmasında New Orleans, Katrina Kasırga deneyimi ile Qinlong/Çin'de Tangshan depremi deneyimini yerel yönetimler açısından karşılaştırmıştır. Çalışmanın sonuçları, bireylerin afet yönetiminin her aşamasına katılımının önemine ve bunun yerel yönetimlerin desteği ile sağlanabileceğine vurgu yapmaktadır (Col, 2007). Bütün bu hedefler, yerel yönetimlerin toplumun afetlere hazır hale getirilmesinde ne derece önemli olduğunu aç1kça göstermektedir.

Çoğu zaman ani olarak ortaya çıkan afetlere karşı etkin bir çözüm bulmak zor olmakla birlikte, ilgili tüm kurumların önceden hazırlanmış planlara dayalı önlemlerle, afet yönetimi sorumluluklarını doğru ve etkin olarak yerine getirmesi mümkündür. Bu nedenle, korunmaya ve afet zararlarının azaltılmasına yönelik tüm planlama ve hazırlık faaliyetleri sorun veya tehlike ortaya çıkmadan önce yapılmalıdır. Gerek afet öncesi gerekse sonrası tüm faaliyetler tek sektörlü veya tek bir kurumun sorumluluğunda olan veya yürütülebilecek faaliyetler değil, çok disiplinli ve süreklilik arz eden faaliyetler bütünüdür. Afet yönetimine ait faaliyetler Zarar Azaltma, Hazırlık, Müdahale ve İyileştirme olmak üzere 4 ana faaliyetten oluşmaktadır (Şekil 1). Zarar azaltma aşamasında alınan önlemler ile olay /olayların durdurulması veya tamamen önlenmesi her zaman mümkün olmayabilir. Bu nedenle Hazırlık aşaması faaliyetleri ile insan canı ve malı ile milli servetlerin afetlerin yıkıcı etkilerinden korunması için bazı faaliyetlerin yürütülmesi gerekir. Operasyona yönelik hazırlık aşaması faaliyetleri zaman zaman zarar azaltma faaliyetlerini de içinde barındırır. Hazırlıklı olmak aynı zamanda, afet halinde yetki ve sorumlulukların belirlenmesi ve destek kaynaklarının düzenlenmesi gibi konularda da hazırlıklı olmayı içerir. Bu aşamada ilgili tüm kurum ve kuruluşlar afet yönetimi görevleri için gerekli iş/görev dağılımını yapmalı, tanımlanan görevleri yerine getirebilmesi için gerekli personel, donanım ve diğer kaynak ihtiyaçlarını tanımlamalıdır. Gerekli ekipman ve donanımların bakımı, tahmin ve erken uyarı sistemlerinin kurulumu ve kullanımı, görevli personelin/personellerin eğitimi ve diğer aktivitelere hazırlık yine bu aşamada yürütülen faaliyetlerdir (Kadıŏglu, 2008; Özmen ve diğ., 2017). Özetle ifade etmek gerekirse, Şekil 1'de şematik olarak gösterilmekte olan Afet Risk Yönetimi faaliyetleri hazırlık, afeti önleme, zarar azaltma gibi 
aktivitelerle tehlikenin olumsuz etkilerinden kaçınmayı ve onları azaltmayı hedeflenmektedir (Şahin, 2016).

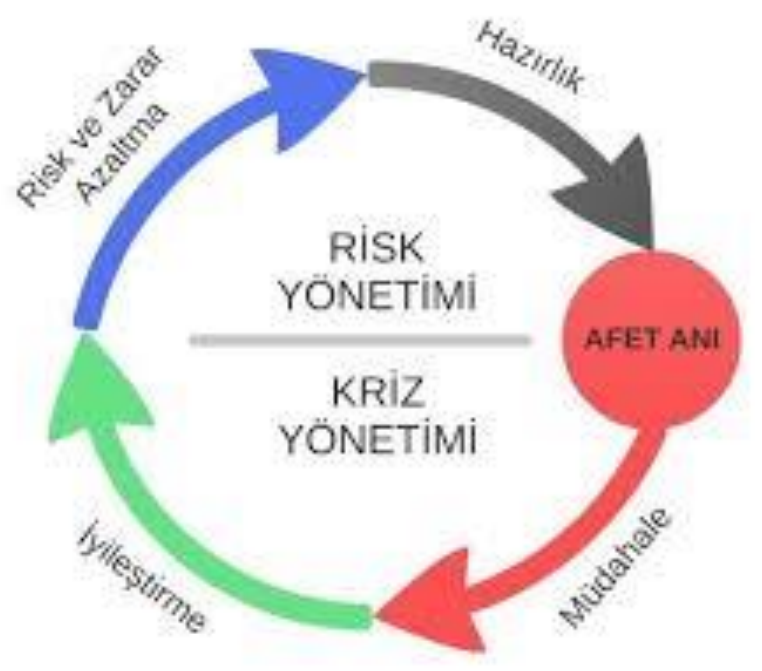

Şekil 1. Afet Yönetimi döngüsü (Gülnerman ve diğ., 2014)

Yerel yönetimler sınırlandırılmış coğrafi bir alanda yaşayan bireylere/topluluğa hizmet üretmek amacı ile kurulan, karar organları, yerel toplulukça seçilen, idari ve mali özerkliğe sahip olan kamu tüzel kişilerdir (Öztürk, 1996). Kuruluş felsefesi gereği yerel yönetimler; halka en yakın olması gereken, afetlere yönelik hazırlık ve zarar azaltma çalışmaları bakımından yerel halkın yapılanmasında vazgeçilmez birimler olarak ön plana çıkmaktadır. Yerel yönetimler aynı zamanda afet yönetiminin afet öncesi, sırası ve sonrası dahil her aşamasında hayati öneme sahip hizmetleri yönetmektedirler. Afet yönetimi alanında uluslararası çalışmaların çoğu bu alanda başarılı sonuçlar elde edebilmek ve daha az zarar görebilir olmak için yerel yönetimlerin etkin rol ve sorumluluklara sahip olmasının önemine vurgu yapmaktadır. Afet risk yönetiminin en yeni kavramlarından biri olan dirençli toplulukların oluşturulması da yerel yönetimlerin öncelikli ve önemli sorumluluklarından biridir (Şahin, 2016).

Bu çalışma ile yerel yönetimlerin afet zararlarının azaltılmasına yönelik sorumlulukları değerlendirilmiştir. Bu kapsamda 1999 depremleri sonrası ülkemizde yerel yönetimler tarafındın yürütülen çalışmalar, 5393 sayılı Belediye kanunu ve 5216 sayılı Büyükşehir Belediye Kanunu ve ilgili tüm yasal düzenlemeler ile Türkiye Afet Müdahale Planındaki yerel yönetimlerin sorumlulukları irdelenmiştir.

\section{YÖNTEM}

Afet tehlike ve risk bilimi, tehlikenin nedenini araştırır. Bir yerleşim yerinde, yüz yıl içerisinde hasar yapabilecek büyüklükteki bir deprem, bir su baskını veya bir heyelan olma olasılığı, on yıl veya bir yıl içerisinde aynı olayların olma olasılığından daha fazladır. Diğer bir ifade ile aynı büyüklükteki bir olayın eşit zaman süresi içerisinde bir bölgede olma olasılığ 1 , köy veya kent gibi belirli bir yerleşim yerinde olma olasıllı̆ıından daha büyüktür. Risk ise, bir olayın ya da tehlikenin doğurduğu olumsuz sonuçların toplamıdır ya da belirli bir büyüklükte meydana gelmesi halinde doğurabileceği kayıp olasılığıdır. Bir afetin meydana gelmesinin tanımını da veren risk, esas itibariyle:

(a) Afet tehlikesinin meydana gelme olasılığ 
(b) Afete maruz kalan yerleşim alanlarının dağılımı,

(c) Afetten ne derece etkilendiklerini belirleyen hasargörebilirlik/zarargörebilirlik

bileşenlerinden oluşmaktadır. Kentleşmeyle birlikte topluluklar üzerinden büyük yıkımlara neden olan afetlerin yönetilmesinde zarar azaltma faaliyetlerinin yerel yönetimler açısından değerlendirilmesi bu çalışmanın yöntemini oluşturmaktadır. Bu amaçla çalışmada "Afet Riski Altındaki Alanların Dönüştürülmesi Hakkında Kanun", "Büyükşehir Belediyesi Kanunu" ve "Belediye Kanunu" ile diğer kentsel altyap1 çalışmaları afet zararlarının azaltılması kapsamında değerlendirilmiştir.

\section{Kanuni Sorumluluklar}

Türkiye'de afet yönetimi; büyükşehir olsun ya da olmasın il kademesinde vali tarafından yönetilmektedir. Yerel yönetimler afet yönetiminde yardımcı birimler olarak rol almaktadır. 2014 yılında yürürlüğe giren Türkiye Afet Müdahale Planı (TAMP) ile afet ve acil durumlara ilişkin müdahale çalışmalarında Yerel Yönetimler, Beslenme, Lojistik, Psikososyal Destek, Enkaz Kaldırma gibi birçok Hizmet Grubunun Destek Çözüm ortağı olarak yer almaktadır (TAMP, 2014).

Diğer taraftan Büyükşehir Belediyelerinin afetler ile ilgili sorumluluklarına yönelik yerel mevzuat incelendiğinde afet risk yönetiminin hazırlık ve zarar azaltma aşamaları, afetlere müdahale ve afet sonrası iyileştirme süreçlerini kapsayan sorumlulukları öne çıkmaktadır (Şahin, 2016). 5216 Sayılı Büyükşehir Belediye Kanununda afetler ile ilgili olarak 7/b-h-i-r maddelerinde afet zararlarının azaltılması çalışmalarını doğrudan ilgilendiren faaliyetlere yönelik sorumluluklar yer almaktadır. Aynı kanunun 7/u maddesi "Ill düzeyinde yapılan plânlara uygun olarak, doğal afetlerle ilgili plânlamaları ve diğer hazırlıkları büyükşehir ölçeğinde yapmak; gerektiğinde diğer afet bölgelerine araç, gereç ve malzeme desteği vermek; itfaiye ve acil yardım hizmetlerini yürütmek; patlayıcı ve yanıcı madde üretim ve depolama yerlerini tespit etmek, konut, işyeri, ĕglence yeri, fabrika ve sanayi kuruluşları ile kamu kuruluşlarını yangına ve diğer afetlere karşı alınacak önlemler yönünden denetlemek, bu konuda mevzuatın gerektirdiği izin ve ruhsatlarl vermek" ve 7/z maddesinde "Afet riski taşlyan veya can ve mal güvenliği açısından tehlike oluşturan binaları tahliye etme ve yıkım konusunda ilçe belediyelerinin talepleri hâlinde her türlü desteği sağlamak" görevleri yer almaktadır. Ayrıca 5216 Sayılı Kanununun 7. Maddesinde yer alan ilçe belediyelerin görev ve yetkilerini belirten paragrafının $\mathrm{f}$ bendi "Afet riski taşıyan veya can ve mal güvenliği açısından tehlike oluşturan binaları tahliye etmek veya yıkmak" hükmü yer almaktadır (BBK, 2004). 5393 Sayılı Belediye Kanununun 53. Maddesinde "Belediye; yangın, sanayi kazaları, deprem ve diğer doğal afetlerden korunmak veya bunların zararlarını azaltmak amacıyla beldenin özelliklerini de dikkate alarak gerekli afet ve acil durum plânlarını yapar, ekip ve donanımı hazırlar" hükmü yer almaktadır. Halka hizmete yönelik sorumlulukları olan yerel yönetimlerin afet yönetimi, afete hazırlık ve zarar azaltma kapsamındaki sorumlulukları afet risklerini azaltmak, afet ve acil durum planı yapmak, ekip ve donanımları hazırlamak ve halkı eğitmek olarak tanımlanabilir (Şahin, 2016).

\section{Kentsel Altyapı Çalışmaları}

Bir kentin kentlilere yeterli ve sağlıklı hizmet sunmasını sağlayacak, kentin işlevini görebilmesi ve gelişmesini sağlayacak içme suyu, kanalizasyon, doğalgaz, vb. yer altı 
sistemlerinin tümü altyapı olarak tanımlanmaktadır. Kent hizmetleri ise yerel yönetimlerin halkın ihtiyaçlarını karşılayabilmek amacıyla yürüttükleri hizmetlerdir (Özdemir, 2016). Kentsel altyapının üst yapı ile nüfus yoğunluğuna hizmet edebilecek yetenekte olması kentin yaşanabilir olmasının göstergelerinden biridir ve teknolojik altyapı yatırımları yüksek sermaye gerektirir.

İçme suyu, kanalizasyon şebeke ve arıtmalarını içeren altyapı tesislerinin doğal afetlere dayanıklı olarak tasarımı ve mühendislik hesapları ile malzeme seçimi, yapımı, işletilmesi, bakım ve onarımı için gerekli asgari şartlara dair usul ve esasları belirlemek amacıyla "Alt Yapılar İçin Afet Yönetmeliği” Resmi Gazetede 15.02.2007 tarih ve 26435 sayı ile yayımlanmıştır. Yönetmeliğin Etüt ve Planlama başlıklı İkinci Bölümünde Etüt Çalışmaları, Planlama Çalışmaları ve Depremler İlgili Performans Hedefleri ile ilgili düzenlemeler yer almaktadır. İçme suyu ve kanalizasyon alt yapı projeleri dahilinde yer alan iletim hatları ve üst yap1 ünitelerinde kaya veya zemin koşullarının belirlenmesi amacıyla yapılacak Jeoteknik Etüt çalışmalarına yönelik düzenlemeler yönetmeliğin Üçüncü Bölümünde yer almaktadır. 5393 sayılı Belediye Kanununun Üçüncü "Belediyenin Görev, Yetki ve Sorumlulukları" bölümü Madde 14'de "Belediye, mahallî müşterek nitelikte olmak şartıyla; a) Imar, su ve kanalizasyon, ulaşım gibi kentsel alt yapı; coğrafì ve kent bilgi sistemleri; çevre ve çevre sağlığl, temizlik ve katı atık; zabıta, itfaiye, acil yardım, kurtarma ve ambulans; şehir içi trafik; defin ve mezarlıklar; ăgaçlandırma, park ve yeşil alanlar; konut; kültür ve sanat, turizm ve tanıtım, gençlik ve spor orta ve yükseköğrenim ögrenci yurtları (Bu Kanunun 75 inci maddesinin son fikrası, belediyeler, il özel idareleri, bağlı kuruluşları ve bunların üyesi oldukları birlikler ile ortağı oldukları Sayıştay denetimine tabi şirketler tarafindan, orta ve yükseköğrenim ögrenci yurtları ile Devlete ait her derecedeki okul binalarının yapım, bakım ve onarımı ile tefrişinde uygulanmaz.); sosyal hizmet ve yardım, nikâh, meslek ve beceri kazandırma; ekonomi ve ticaretin geliştirilmesi hizmetlerini yapar veya yaptırır. (Mülga son cümle: 12/11/2012- 6360/17 md.) (...) (Ek cümleler: 12/11/2012-6360/17 md.) Büyükssehir belediyeleri ile nüfusu 100.000'in üzerindeki belediyeler, kadınlar ve çocuklar için konukevleri açmak zorundadır. Diğer belediyeler de mali durumları ve hizmet önceliklerini değerlendirerek kadınlar ve çocuklar için konukevleri açabilirler." denmektedir.

\section{Kentsel Dönüşüm}

Kentsel Dönüşüm Yasası olarak da bilinen 31.05.2012 tarih, 28309 sayı ve 6306 kanun numaralı "Afet riski altındaki alanların dönüştürülmesi hakkında kanun" ve 15 Aralık 2012 tarih ve 28498 sayılı "Afet Riskleri altındaki alanların dönüştürülmesi hakkında kanunun uygulama yönetmeliği” bozulmaya ve çökmeye uğrayan kentsel alanların, kentin gecekondu alanlarının, olası bir afette kentin en fazla zarar görmesi muhtemel olan alanlarının ve çevresel koşullarının kapsamlı ve bütünleşik yaklaşımlarla iyileştirilmesine yönelik olarak uygulanan strateji ve eylemlerin tümü olarak ifade edilebilir.

Ayrıca, 03.07.2005 tarih ve 5393 sayılı "Belediye Kanunu" madde 73 (Değişik: 17/6/2010-5998/1 md.) 'e göre "Belediye, belediye meclisi kararlyla; konut alanlarl, sanayi alanlarl, ticaret alanlarl, teknoloji parkları, kamu hizmeti alanlarl, rekreasyon alanları ve her türlü sosyal donatı alanları oluşturmak, eskiyen kent kisımlarını yeniden inşa ve restore etmek, kentin tarihi ve kültürel dokusunu korumak veya deprem riskine 
karşı tedbirler almak amacıyla kentsel dönüşüm ve gelişim projeleri uygulayabilir." ifadesi yer almaktadır (BK, 2005).

Kentsel dönüşüm ile;

- Fiziksel, işlevsel, ekonomik ve sosyal ömrünü tamamlamış kent dokuları doğal ve kentsel riskleri dikkate alarak iyileştirilmekte,

- Daha iyi barınma koşulları, ticaret ve sanayi olanakları, tüm kentsel donatıların sağlanması amaciyla kentlerin ve kent merkezlerinin tümü ya da bir bölümü günün değişen koşullarına daha iyi yanıt verebilecek şekilde yeniden planlanmakta ve projelendirilmekte,

- Ekonomik ve yapısal özellikleri iyileştirilmesine olanak vermeyecek ölçüde kötüleşmiş olan çöküntü bölgeleri ve bunların oluşturduğu kent bölümleri yeni bir planlama düzeni içinde yeniden ele alınmaktadır (URL-2).

Kentsel dönüşüm aşağıda belirtilmiş alanlarda ve amaçla yapılmaktadır.

- Göç ve nüfus artışı nedeniyle oluşan gecekondu alanları ile, mühendislik gereklerine uymayan yapılaşma sonucu sağlıksız ve plansız kentleşmiş alanların dönüştürülmesi,

- Kentlerin içerisinde kalmış, ekonomik ömrünü tamamlamış ve işlevini yitirmiş sanayi alanlarının dönüştürülmesi,

- Doğal afetler sonucu yıkılan veya risk taşıyan alanların yeniden işlevlendirilmesi ya da sağlıklaştırılması,

- Tarihi dokudaki fiziksel çöküşün durdurulması, tarihi değerlerin gün ışığına çıkarılması ve yeni işlevler kazandırılarak kullanıma açılması (URL-2).

\section{Toplum Tabanlı Afet Eğitimleri}

Toplumun afetlere hazır, daha az zarar görebilir hale getirilmesinde farkındalı̆̆ın artırılması önemli bir role sahiptir. Farkındalık öğrenilebilen bir beceridir. Afet farkındalığının geliştirmenin yollarından biri yaşanan afet tecrübesi bir diğeri de eğitimdir. AFAD'ın 2014 yılında 4038 hane (2.816'sı kent ve 1.380'i kır) üzerinde gerçekleştirdiği "Türkiye Afet Farkındalığı ve Afetlere Hazırlık Araştırması" sonuçları afet farkındalığının artırılmasına yönelik yapılacak çalışmaların, toplumun özellikle daha az eğitim almış bireylerine yönelik olarak yoğunlaşması gerektiğini göstermektedir. Katılımcıların \%40.7 (f=1.643)'si yaşadığı bölgedeki muhtemel afetler konusunda bilgilendirmesi gerektiğini, \%26.8 ( $\mathrm{f}=1.083$ )'i afetlerle ilgili etkinliklerin yapılması gerektiğini düşünmektedir. Bu sonuçlar, ülkemizde yoğun olarak maruz kaldığımız afetlerle ilgili eğitimlerin özellikle bölgesel riskleri dikkate alarak çeşitlendirilmesi gerektiğini göstermektedir (AFAD, 2014). Bu noktada yerel yönetimlere büyük sorumluluklar düşmektedir. Yerel yönetimler, Afet ve Acil Durum Yüksek Kurulu 2014/1 say1lı kararı 3. maddesine "Afet zararlarının azaltılmasl, afete hazırlık kültürü ve afet gönüllülük bilinci oluşturulması amacıyla Afet ve Acil Durum Yönetimi Başkanlı̆̆ının öncülügüunde başlatılan Afete Hazır Türkiye bilinçlendirme ve eğitim projesi kapsamında afet öncesi, sırası ve sonrasında doğru davranış şekilleri ile alınabilecek temel önlemlere yönelik bilgi ve beceri kazandırllmast hedeflenmekte olup bu çerçevede tüm kurum ve kuruluşların acil eylem planlarını hazırlamalarına ve gerçekleştirilen kurumsal ve toplum tabanl ĕgitim faaliyetlerine katılım ve desteğin sağlanmasına" dayanarak AFAD ile işbirliği içerisinde kendi güç ve imkanları 
doğrultusunda halkın eğitilmesine destek sağlamalıdır. Ülkemizde birçok büyükşehir ve il belediyesi kendi güç ve imkanları doğrultusunda afetlere yönelik teorik ve uygulamalı eğitimler gerçekleştirmektedir. Bu eğitimlerin yanı sıra İstanbul, İzmir, Kocaeli, Kadıköy başta olmak üzere birçok belediyenin afet eğitimleri ile ilgili basılı eğitim materyalleri ve kitapları da mevcuttur. Ancak bireylere en yakın kurumlar olan belediyelerin yürüttükleri bu tür farkındalık ve eğitim faaliyetlerinin belirli bir standartta ve ilgili kurumlarla işbirliği içerisinde yürütülmesinin gerekliliği unutulmamalıdır.

\section{SONUÇ}

Afet sonrasında oluşan doğrudan ve dolaylı olumsuz etkilerin giderilebilmesi, afet öncesi zarar azaltma ve hazırlık faaliyetleri ile normal yaşama en hızlı şekilde dönebilme çabaları afet yönetim sisteminin öncelikli hedefidir. Toplumsal yaşamı kesintiye uğratan afetlere karşı en etkin sistem, normal yaşantıya dönüşü en çabuk sağlayabilen sistemdir. Bütünleşik afet yönetim sistemi, afetlerin öncesi ve sonrasıyla bir bütün olarak ele alınmasını ve sadece afete müdahale kapsamında algılanmamasını önemle vurgular. Afetlerin acil durumlardan farklı olarak bir bölge veya ülke düzeyinde etkili olabilecek yapıda olması ve ileri düzeyde koordinasyon gerektirmesi nedeniyle bu konudaki sorumluluğun kamu yönetimi tarafından üstlenilmesi zorunlu olarak görünmekle birlikte mevcut alt ve üst yapıya ait teknik bilgiler ile hızlı ve etkili müdahale için kaynakların etkin kullanımı ve teknolojiye duyulan ihtiyaçlar dikkate alındığında sonuca odaklı bütüncül bir yapının gerekliliği ortaya çıkmaktadır. Gelişen dünyada, değişen iklim koşulları, hızla artan nüfus, plansız kentleşme gibi birçok nedenlere bağlı olarak insanlar doğal ya da insan kaynaklı (teknolojik) afetlere artarak maruz kalmaktadır. Özellikle kaynağ 1 doğadan gelen, ekonomik ve sosyal kayıp ve zararlara sebep olan afetlerin yönetilebilmesi en önemli konulardan biridir ve risklerin azaltılması ile afetlere dirençli birey/toplulukların oluşturulması noktasında halka en yakın birim olan yerel yönetimlere ve özellikle belediyelere önemli görevler düşmektedir (Şahin, 2016). Gerek teknik gerekse eğitim gibi toplumsal tüm çaba ve girişimlerin ilgili tüm kurumların işbirliğinde, belirli bir sistematik ve standartta olması gerekir. Bu çalışmada büyükşehir veya il belediyelerinin yerelde yürüttükleri afet zararlarının azaltılmasına yönelik çalışmalar yasal dayanaklar çerçevesinde değerlendirilmiştir. Büyükşehir olsun veya olmasın 2014 yılında yürürlüğe giren TAMP ile afet ve acil durum yönetiminde belediyeler birçok hizmet grubunda destek hizmet grubunun çözüm ortağı olarak görev ve sorumluluklara sahipken, 5393 sayılı Belediye Kanununa göre imar, su ve kanalizasyon, ulaşım gibi kentsel alt yapı; coğrafî̀ ve kent bilgi sistemleri; çevre ve çevre sağlığı, temizlik ve katı atık; zabıta, itfaiye, acil yardım, kurtarma ve ambulans hizmetleri başta olmak üzere birçok hizmeti karşılamakla yükümlüdür. Konumu ve gücü itibariyle İstanbul Büyükşehir Belediyesi Acil Yardım Hizmet Gruplarında ilgili birimleriyle afet hallerinde kendi bünyesinde kurtarma, müdahale, sosyal hizmet ve diğer faaliyetlerin eşgüdümünü sağlamak amaciyla Afet Koordinasyon Merkezi (AKOM)'ni kurmuştur. Bu merkez, olası bir afet halinde, İl Kriz Merkezi ile de eşgüdüm sağlayarak Büyükşehir Belediyesinin tüm birimleri ve bağlı kuruluşları arasında iletişim ve işbirliğini sağlamayı hedeflemektedir. Büyükşehir Belediyesi ayrıca, depreme hazırlık faaliyetleri kapsamında afet müdahale merkezleri kurmuş, yer hareketlerini izleyen projeler geliştirmiştir (Uzunçıbuk, 2005). Karasu (2012) tarafindan belediyelerle ilgili yapılan GZFT analizi sonuçlarına göre birçok belediye mali imkânlarının azlığı, personelin yetersizliği, kanunlardan kaynaklanan zorluklar, altyapı eksiklikleri, plansızlığın neden olduğu kaçak yapılaşma gibi birçok 
sorunla karşı karşıya görünmektedir. Yine aynı çalışmada; işsizlik, göç, trafik yoğunluğu, plansızlık, çevre kirliliği incelenen tüm büyükşehir belediyeleri tarafından bir tehdit olarak algılanmaktadır (Karasu, 2012). Yaşanan bahse konu sorunlar nedeniyle birçok ilde "Afet riski altındaki alanların dönüştürülmesi hakkında kanun" gereğince riskli alanlarda dönüşüm projelerinin üretilmesi çıkmaza girmektedir. Yerel düzeyde afetlerle mücadele kapasitesinin gerek teknik gerekse toplumsal boyutta artırılmasına yönelik yasal düzenlemeler yürürlükte olmasına rağmen ülkemizde afet zararlarının azaltılmasına yönelik çalışmalar henüz uygulama açısından istenilen seviyeye ulaşamamış olarak görünmektedir.

\section{KAYNAKÇA}

AFAD, (2014), Türkiye Afet Farkındalığı ve Afetlere Hazırlık Araştırması,

5216 BÜYÜKŞEHİR BELEDIYYE KANUNU (BBK), (2004), http://www.mevzuat.gov.tr/MevzuatMetin/1.5.5216.pdf, Tertip: 5 Cilt: 43, R.G.

5393 SAYILI BELEDIYE KANUNU (BK), (2005), http://www.mevzuat.gov.tr/MevzuatMetin/1.5.5393.pdf, Tertip:5, Cilt: 44, R.G.

Col, Jeanne-Marie (2007), Managing Disasters: The Rol of Local Goverment, Public Administration Review, Vol: 67, No:1, ss: 114-124.

Ergünay, O., (2006), Mikrobölgeleme Çalışmaları ve Afet Senaryoları, JICA-Içişleri Bakanlığı Belediye Elemanları için Düzenlenen Zarar Azaltma Ĕ̆itimi Kursu,

Ergünay, O., (2002), Afete Hazırlık ve Afet Yönetimi, Türkiye Kızllay Derneği Genel Müdürlüğ̈̈ Afet Operasyon Merkezi (AFOM), Ankara, (2002).

Gülnerman, A., Tezer, A., Göksel, Ç., (2014), Kriz Yönetiminde Konumsal Tabanlı Bir İletişim Modeli Önerisi Ve Mevcut Uygulamalarla Karşılaştırılması, 5. Uzaktan Algılama-Cbs Sempozyumu (UZAL-CBS 2014), 14-17 Ekim 2014, İstanbul

Kadıoğlu, M., (2008), Modern, Bütünleşik Afet Yönetimin Temel İlkeleri; Kadığlu, M. ve Özdamar, E., (editörler), Afet Zararlarını Azaltmanın Temel İlkeleri, JICA Türkiye Ofisi Yayınları No: 2, Ankara. s. 1-34

Karasu, M.A., (2012), Büyükşehir Belediyelerinde Stratejik Planlama: Karşılaştırmalı Bir Analiz, Uluslararası Yönetim İktisat ve Isşletme Dergisi, Cilt 8, Sayı 16, ss. 159-180

Kuterdem, K., Akın, D., Nurlu, M., (2009), Afet Zararlarının Azaltılmasında Birleşmiş Milletler Kaynaklı Çalışmalar ve 2005-2015 Yılları Arasında Bir Yol Haritası Olarak Hyogo Çerçeve Eylem Planı. Türkiye’nin Afet Yönetimi 11nci yuvarlak Masa Toplantısı, ODTÜ, Ankara.

Macit, İ., (2019), Bütünleşik Afet Yönetiminde Sendai Çerçeve Eylem Planının Beklenen Etkisi, Artvin Çoruh Üniversitesi Doğal Afetler Uygulama ve Araştırma Merkezi Doğal Afetler ve Çevre Dergisi, 5(1): 175-186, DOI: 10.21324/dacd.421564

Özdemir, M., (2016), Belediyelerin Altyapı Hizmeti Sunumunda Vatandaş Memnuniyeti: Anamur Belediyesi Örneği, Yüksel Lisans Tezi, Adnan Menderes Üniversitesi Sosyal Bilimler Enstitüsü Siyaset Bilimi Ve Kamu Yönetimi Anabilim Dalı 
Özmen, B., Özden, A.T., Gerdan, S., Tezgider, G., Gökçe, O., (2017), Afet Yönetimi-I, Anadolu Üniversitesi, AÖF Yayınları, Yayın No: 236, ISBN: 978-975-06-2139-0

Öztürk, A., (1996), Türkiye'de Halkın Yönetime Katılması, Mevcut Yerel Yönetim Anlayışı ve Çözüm Bekleyen Temel Sorunlar, Çukurova Üniversitesi, Sosyal Bilimler Enstitüsü Dergisi, Say1:4, Cilt:4, ss: 105-116.

Şahin, G., (2016), Yerel Yönetimlerde Afetlere Hazırlık ve Zarar Azaltma Sorumlulukları: İzmir Büyükşehir Belediyesi Örneği, KAYSEM 10- Kamu Yönetimi Seтровуити, 935-966.

Toprak Karaman, Z., (2000), Yönetim Stratejilerindeki Gelişmeler, TiD, Y. 72, S 26.

TÜRKIYE AFET MÜDAHALE PLANI (TAMP), (2014), http://www.resmigazete.gov.tr/eskiler/2014/01/20140103-12.htm, R.G. 28871

Uzunçıbuk, L. (2005), Yerleşim Yerlerinde Afet Ve Risk Yönetimi, Doktora tezi, Ankara Üniversitesi, Sosyal Bilimler Enstitüsü.

Varol, N., Kırıkkaya, E.B., (2017), Afetler Karşısında Toplum Dirençliliği, Journal of Resilience, Cilt 1, Say1 1, https://dx.doi.org/10.32569/resilience.344784

Yavaş, H., (2005), Türkiye'de Doğal Afetlerin Merkezi-Yerel İlişkiler Açısından Yönetim Sorunu, Dokuz Eylül Üniversitesi, Sosyal Bilimler Enstitüsü Dergisi, Cilt 7; Sayı 3.

URL-1 https://www.preventionweb.net/drr-framework/sendai-framework

URL-2. https://www.kocaeli.bel.tr/webfiles/userfiles/files/birimler/imar-ve-sehircilikdairesi-baskanligi/kentsel-donusum-ve-gelisim-planlama-subemudurlugu/KENTSEL_DONUUM_GEL\%C4\%B0\%C4\%B0M_VE_PLANLAMA_M ASTER_PLANI.pdf 